\title{
Sosiodraama ja luovat ryhmämenetelmät konsultoinnissa
}

\author{
Martti Lindqvist \\ Nykyaikaisessa konsultaatiossa, työnohjauksessa ja \\ työn kehittämisessä on yhä enemmän pantu \\ painoa luoville, intuitiivisuutta korostaville \\ työmenetelmille ja ryhmäprosessin tietoiselle \\ hyväksikäytölle. Oikein ja tehokkaasti käytettyinä \\ nämä menetelmät tuottavat intensiivistä \\ kokemuksellista oppimista sekä lisäävät roolien ja \\ ryhmädynamiikan ymmärtämistä.
}

Olen käyttänyt näitä menetelmiä jo kymmenen vuoden ajan yhdessä FK, organisaatiokonsultti Seija Mansneruksen kanssa johtamissamme työnohjaaja- ja konsulttikoulutuksissa. Nykyään Suomessa järjestetään myös lukuisia psyko- ja sosiodraaman erityiskoulutuksia, joiden laajuus vaihtelee kaksivuotisista menetelmäkoulutuksista aina noin kuusivuotisiin vaativaa erityistasoa vastaaviin ohjaajakoulutuksiin. Koulutusryhmät ovat tavallisesti moniammatillisia ja menetelmiä sovelletaan yhä useammilla kasvatuksen, hoidon, sosiaalityön, liike-elämän luovan työskentelyn alueilla.

$\mathrm{E}$ lämän kuvaamista ja itsensä ilmaisemista roodien kautta ja draaman muodossa tuskin voidaan pitää kenenkään keksintönä. Se on ikiaikaista alkuperää ja liittyy toisaalta yhteisöjen kollektiiviseen alitajuntaan ja toisaalta ihmisen spontaaniin ilmaisutarpeeseen sekä tietoisuuteen omasta sisäisyydestään. Esimerkiksi useimmat rituaalit ovat elämän kuvaamista, hallintaa ja muuttamista draa- mallisessa muodossa. Kautta aikojen on ollut uskonnollisia, sosiaalisia ja esteettisiä rituaaleja. Nykyaikanakin esimerkiksi uskonnolliset kultit, poliittiset foorumit ja oikeudenkäyttö noudattavat rituaalinomaisen draaman muotoja. Ne ilmentävät ankkuroitumista tiettyyn pitkään perinteeseen ja korostavat toiminnan yliyksilöllistä, sosiaalisiin ja kosmisiin rooleihin liittyvää luonnetta.

Luovaa draamaa käytetään teattereiden lisäksi esimerkiksi kasvatuksessa, terapiassa ja työyhteisötyöskentelyissä. Yhteistä näille sovelluksille on toiminnallisuuden, ilmaisullisuuden, fyysisyyden, vuorovaikutuksen ja spontaanisuuden korostaminen. Työskentelyjen asteikko ulottuu portaattomasti yksinkertaisista mielikuvaharjoituksista ja roolileikeistä laajoihin draamallisiin ryhmäprosesseihin.

Sosiodraaman, psykodraaman ja sosiometrian 


\section{K A T S A U K S I A}

“isä” Jacob Moreno vaikutti tämän vuosisadan alkupuoliskolla ensiksi Itävallassa, Wienissä, ja sitten Yhdysvalloissa kehittäen sosiometriaa ja spontaanin draaman teoriaa. Hän oivalsi, että tiettyjen sosiaalisten tai henkilökohtaisten kysymysten käsittely näyttämöllä improvisoidun draaman muodossa oli tehokas väline muutoksien aikaansaamiseksi yksilöiden ja yhteisöjen elämässä, koska se mahdollistaa syvällä kulkevan tunnetyöskentelyn sekä rooliharjoittelun. Moreno itse työskenteli mm. näyttelijöiden, prostituoitujen, siirtotyöläisten, laitosasukkaiden, sotilaiden ja mielisairaiden parissa. Vähitellen Moreno sai arvostetun aseman amerikkalaisessa ryhmäpsykoterapiassa ja hän lienee nykyisin kiistattomin auktoriteetti sosiometrian, draamaterapian ja sosiodraaman alueella.

$\mathrm{J}$ acob Morenon kehittämä spontaanin draaman teoria pohjautuu sosiometriaan, psykodraamaan ja sosiodraamaan. Sosiometrialla tarkoitetaan ryhmien suhde- ja vuorovaikutusrakenteiden osallistuvaa tutkimusta, mikä tapahtuu ennen kaikkea tekemällä näkyväksi niitä valintoja ja mielikuvia, jotka määrittelevät yksilöiden aseman ryhmässä eri kriteereiden kannalta arvioituina. Sosiometrisessä työskentelyssä ryhmä tutkii ohjaajansa johdolla omaa sisäistä rakennettaan ja prosessiaan. Tyypillisiä sosiometrisiä kysymyksiä ovat esimerkiksi seuraavat: "Kenet koet tässä ryhmässä juuri nyt itsellesi kaikkein läheisimmäksi?" "Kuka on sinulle tässä huoneessa kaikkein vaikein henkilö." "Kenellä mielestäsi tässä ryhmässä on eniten valtaa?" Vastauksista voidaan luoda suhdekarttoja joko piirtämällä tai muodostamalla työskentelytilaan ryhmän jäsenistä kuvio, missä etäisyydet ja asennot ilmaisevat suhteiden laatua.

$\mathrm{K}$ un ryhmä tulee tietoiseksi omasta rakenteestaan, se vaikuttaa muuttavasti ryhmän työskentelyyn. Syntyy jatkuva orgaaninen prosessi, missä ryhmän toiminta ja ryhmän tilan tutkiminen vuorottelevat. Myös sosiodraamojen sisällä tai niiden analyysissa voidaan käyttää sosiometrisiä työskentelyjä.

Morenon sanoin: "Sosiometrisen työskentelyn tarkoituksena on muuttaa vanha sosiaalinen rakenne uudeksi. Se on omiaan muuttamaan ryhmä-

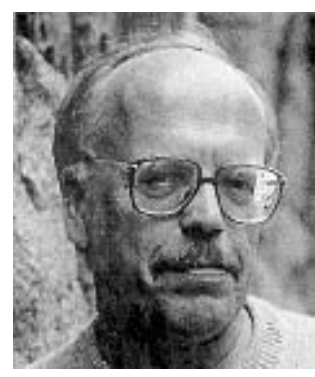

Martti Lindqvist

rakenteita - mikäli niin on tarpeen - sellaisiksi, että ryhmän ulkoinen muoto vastaa mahdollisimman tarkasti sen syvärakennetta."

$\mathrm{M}$ orenolaisessa teoriassa oletetaan, että ihmisellä on luonnostaan "toiminnan nälkä” (action hunger), jonka vapauttaminen mahdollistaa spontaanin oppimisen ja työskentelyn. Työskentelyn keskeisenä periaatteena on "asioiden tekeminen ja näyttäminen". Ryhmän jäsenet elävät läpi persoonansa kaikilla tasoilla jotakin tarinaa ja kohtaavat myös toisensa eri rooleissa - esimerkiksi vaihtamalla rooleja keskenään. Juuri tämä eläytyvä roolityöskentely tuo draamaan siihen aina kuuluvan terapeuttisen elementin. Samalla tapahtuu roolioppimista. Ryhmäläiset saavat käyttöönsä uusia malleja ja kykyjä, jotka tosin ovat heissä olleet luovina mahdollisuuksina, mutta eivät ole päässeet tietoiseen käyttöön.

Cosiodraama on ohjaajan johdolla tapahtuva luova ryhmäprosessi, jossa rooleihin eläytymisen ja niissä toimimisen kautta tutkitaan jotakin yhteisöllistä ongelmaa, rakennetta tai tilannetta. Tarkoituksena on eläytyä, oivaltaa ja integroida yhteistä kokemusta sekä muuttaa sosiaalista todellisuutta vastaamaan entistä paremmin inhimillisiä vuorovaikutustarpeita, ihmisarvon ja oikeudenmukaisuuden vaatimuksia. Sosiodraaman avulla voidaan parhaassa tapauksessa päästä luovaan yhteisölliseen ongelmanratkaisuun. Sosiodraamatyöskentelyssä tärkeimpinä käyttöaineksina ovat yksilöiden elämys ja oivallus, mutta työskentely alkaa laajasta kokonaisuudesta, "ihmistä suuremmasta todellisuudesta" ja päätyy myös siihen.

Sosiodraama perustuu siihen, että kaikkiin inhi- 
millisiin rooleihin liittyy sekä yksilöllinen että kollektiivinen puoli. Ihminen on luonnostaan "roolin esittäjä”. Roolit voivat olla fyysisiä, psyykkisiä, sosiaalisia ja kosmisia. Yhteisön sisällä persoonallinen ja sosiaalinen taso ovat jatkuvassa vuorovaikutuksessa. Ryhmän roolikenttä on enemmän kuin yksittäisten roolien summa. Sosiodraamassa onkin kyse tietyllä tavalla ryhmän kollektiivisesta identiteetistä.

Ainakin väljässä merkityksessä sosiodraamaa voidaan pitää myös terapeuttisena työskentelynä. Moreno puhui ryhmäkatharsiksesta, millä tarkoitetaan koko ryhmää koskevaa kokemuksellista puhdistumista. Koska sosiodraaman lähtökohtana on aina jokin ulkoiseen todellisuuteen liittyvä kysymys, myös työskentelyn keskeiseksi tulokseksi haetaan ulkomaailmaa jäsentävää ja muuttavaa oivallusta.

$\mathrm{D}$ raamatyöskentely jakautuu tavallisesti neljään osaan. Se lähtee liikkeelle virittäytymisestä, missä tarkoituksellisesti pyritään nostamaan ryhmän spontaanisuutta esimerkiksi mielikuvilla, fyysisellä liikkeellä tai ryhmäläisten välillä tapahtuvalla vuorovaikutuksella. Tämän jälkeen seuraa varsinainen draamajakso, joka on rooleihin perustuvaa improvisoitua ryhmätyöskentelyä tiettyyn teemaan, ongelmaan tai tilanteeseen liittyen. Työskentelyn tämä vaihe päättyy jakamiseen (sharing), missä ryhmä purkaa tunnetasolla kokemaansa ja antaa palautetta jäsenilleen. Tavallisesti myöhemmin tehdään erikseen myös työskentelyn prosessointi, missä perästä päin tarkastellaan tapahtunutta ryhmäprosessia asiatasolla ja teoreettisesti sekä pyritään integroimaan tehty työskentely osaksi aikaisempaa kokemusta, tietoa ja teoriaa. Tässä yhteydessä teorialla ei tarkoiteta vain draamateoriaa, vaan ylipäätään kaikkea sitä, mitä ennestään tiedetään ja ymmärretään työskennellystä aiheesta.

$\mathrm{O}$ hjaajan tehtävänä on virittää ryhmän luovuutta, tehdä tarkkoja havaintoja, tukea vaikeissa rooleissa ja tilanteissa olevia, ruokkia prosessia virikkeitä antamalla ja väliintuloja tekemällä, seurata johtolankoja, luoda hypoteeseja ja kehittää tulkinoja. Omilla energioillaan ja reaktioillaan ohjaaja voi myös vaikuttaa draaman "nousuihin ja laskuihin". Vahvasta persoonallaan osal- listumisesta huolimatta ohjaaja ei saa toteuttaa draamaa ohjatessaan “omaa käsikirjoitustaan", vaan hänen on annettava prosessin muotoutua ryhmässä spontaanisti syntyvän vuorovaikutuksen ja tunneilmaisun perusteella eteneväksi.

Konsultaatiossa ja työnohjauksessa roolityöskentelyt ja draama palvelevat tietenkin perustehtävää. Etenkin sosiometriset tarkastelut ja roolien kautta asioiden kokemuksellinen havainnollistaminen antavat tärkeää materiaalia vallitsevan tilanteen ymmärtämiselle ja luovat edellytyksiä työskentelyn päämäärien saavuttamiselle.

\section{PSYKO-JASOSIODRAAMAAN LIITTYVÄÄKIRJALLISUUTTA}

BLATNER, H.A. (1997) Toiminnalliset menetelmät terapiassa ja koulutuksessa. Resurssi, Naantali.

KELLERMAN, Peter Felix (1992) Focus on Psychodrama. The Therapeutic Aspects of Psychodrama. London and Philadelphia.

LEUTZ, Grete (1986) Psychodrama. Theorie and Praxis. 1. Das klassische Psychodrama nach J.L. Moreno. Heidelberg - New York.

LINDQVIST, Martti (1992) Unelma rohkeasta elämästä. Ryhmämatkoja luovuuteen. Otava, Helsinki.

MARINEAU, René F. (1989) Jacob Levy Moreno 1889 1974. Routledge.

MORENO, J.L. (1953) Who Shall Survive? Foundations of Sociometry, Group Psychotherapy and Sociodra$m a$. Beacon House Inc. Beacon, N.Y.

MORENO, J.L. (1985) Psychodrama. First Volume. Fourth Edition with New Introduction. Beacon House, Inc. Ambler, PA. 1985.

NIEMINEN, Seija \& Saarenheimo, Marja (1981) Morenolainen psykodraama. Historiallinen ja filosofispsykologinen analyysi. Helsinki.

STERNBERG, Patricia \& Garcia, Antonina (1989) Sociodrama. Who's in Your Shoes? New York- London.

VALVE-MÄNTYLÄ, Liisa Inari (1992) Morenolainen rooliteoria ryhmän työnohjauksen viitekehyksenä. Aikuiskasvatustieteen syventävien opintojen tutkielma. Kasvatustieteen laitos, Helsinki.

WILLIAMS, Antony (1991) Forbidden Agendas. Strategic action in groups. London and New York.

WILLIAMS, Antony (1989) The Passionate Technique. Strategic psychodrama with individuals, families and groups. London and New York. 